\title{
Computer Simulation of the Multiphase Flow in a Peirce-Smith Copper Converter
}

\author{
Oscar Barrios, Miguel A. Barron, Dulce Y. Medina, Isaias Hilerio \\ Departamento de Materiales, Universidad Autonoma Metropolitana Azcapotzalco, Ciudad de Mexico, Mexico \\ Email:bmma@correo.azc.uam.mx
}

How to cite this paper: Barrios, $\mathrm{O}$. Barron, M.A., Medina, D.Y. and Hilerio, I. (2018) Computer Simulation of the Multiphase Flow in a Peirce-Smith Copper Converter. Open Journal of Applied Sciences, 8, 296-303.

https://doi.org/10.4236/ojapps.2018.87022

Received: June 19, 2018

Accepted: July 23, 2018

Published: July 26, 2018

Copyright $\odot 2018$ by authors and Scientific Research Publishing Inc. This work is licensed under the Creative Commons Attribution International License (CC BY 4.0).

http://creativecommons.org/licenses/by/4.0/

\begin{abstract}
The multiphase flow in a Peirce-Smith copper converter is numerically explored in this work. Molten matte, molten slag and air are the phases considered. The transient partial differential equations that constitute the mathematical model are discretized using a two-dimensional computational mesh. The Computational Fluid Dynamics technique is employed to numerically solve the discretized equations. The aim of the numerical analysis is to study the influence of the nozzle height on the phase distributions inside the converter. Three values of the nozzle heights are considered.
\end{abstract}

\section{Keywords}

Computational Fluid Dynamics, Copper Converter, Multiphase Flow, Nozzle Height, Peirce-Smith Converter

\section{Introduction}

At industry, the majority of the blister copper is produced today by means of the Peirce-Smith converter (PSC), in which air is injected to oxidize sulfur and chemically reduce copper. Besides, silica flux is added to the converter in order to form a slag which captures the matte impurities [1]. The air is injected into the molten copper matte through submerged nozzles [2].

In the PSC an intense momentum transfer is required to get high heat transfer and chemical reaction rates. In some papers, physical experiments on water models are reported to analyze the bubbling to jetting flow regimes in copper converters [2] [3] [4] [5]. In recent years, computer simulations have been carried out in order to understand the fluid flow in these devices. Recently, the Computational Fluid Dynamics (CFD) technique is employed to study the flow dynamics in copper converters [6] [7] [8] [9]. 
Here, the multiphase flow in a PSC is analyzed using the CFD technique. Three phases are considered: molten copper matte, molten slag, and air. Three nozzle heights are considered in the two-dimensional transient computer simulations, namely $0.1,0.25$ and $0.5 \mathrm{~m}$.

\section{Mathematical Model}

The conservation of momentum and mass of the considered phases (molten matte, molten slag, air) is modeled using the Navier-Stokes and the continuity equations [10]. To simulate the turbulence, the K- $\varepsilon$ model is selected [11]. To represent the multiphase flow, the Volume of Fluid (VOF) model [12] is employed, whose derivation rests on the assumption that two or more phases are not interpenetrating. In this model it is assumed that in each control volume the volume fractions of all phases sum to unity, and the interface between the phases is obtained by solving the continuity equation for each phase. For the pressure-velocity coupling, the Pressure Implicit with Splitting Operations (PISO) algorithm is selected [13].

\section{Numerical Solution}

Computational Fluid Dynamics (CFD) software is employed to numerically solve the mathematical model [13] [14]. The transient partial differential equations that constitute the mathematical model are discretized using a two-dimensional computational mesh composed of 12,000 trilateral cells [15].

The current phases and physical dimensions of a slice of the copper converter are shown in Table 1 and Figure 1. The operating conditions prevailing during the computer simulations are shown in Table 2 . Air injection velocity is kept at $10 \mathrm{~m} \cdot \mathrm{s}^{-1}[16]$. The properties of the considered phases are shown in Table 3. In order to keep the numerical stability during the integration of the mathematical model equations, a time step value of $0.001 \mathrm{~s}$ is employed in the computer runs.

\section{Results of Numerical Simulations}

During the numerical simulations three values of the nozzle height were considered: $0.1,0.25$ and $0.5 \mathrm{~m}$. As is shown in Table 2, the values of the matte height,

Table 1. Physical dimensions of the Peirce-Smith copper converter.

\begin{tabular}{cc}
\hline Converter diameter, $\mathrm{m}$ & 4.0 \\
Nozzle diameter, $\mathrm{m}$ & 0.05 \\
Off gas exit diameter, $\mathrm{m}$ & 0.5 \\
Nozzle height, $\mathrm{m}$ & $0.10,0.25,0.5$ \\
\hline
\end{tabular}

Table 2. Operating conditions of the converter [16].

\begin{tabular}{cc}
\hline Matte height, $\mathrm{m}$ & 2.0 \\
Slag height, $\mathrm{m}$ & 0.1 \\
Air injection velocity, $\mathrm{m} \cdot \mathrm{s}^{-1}$ & 10 \\
\hline
\end{tabular}


Table 3. Physical properties of the considered phases [1].

\begin{tabular}{cccc}
\hline Property & Air & Slag & Matte \\
\hline Density, $\mathrm{kg} \cdot \mathrm{m}^{-3}$ & 1.225 & 2500 & 5200 \\
Viscosity, $\mathrm{kg} \cdot \mathrm{m}^{-1} \cdot \mathrm{s}^{-1}$ & $1.0789 \times 10^{-5}$ & 0.05 & 0.004
\end{tabular}

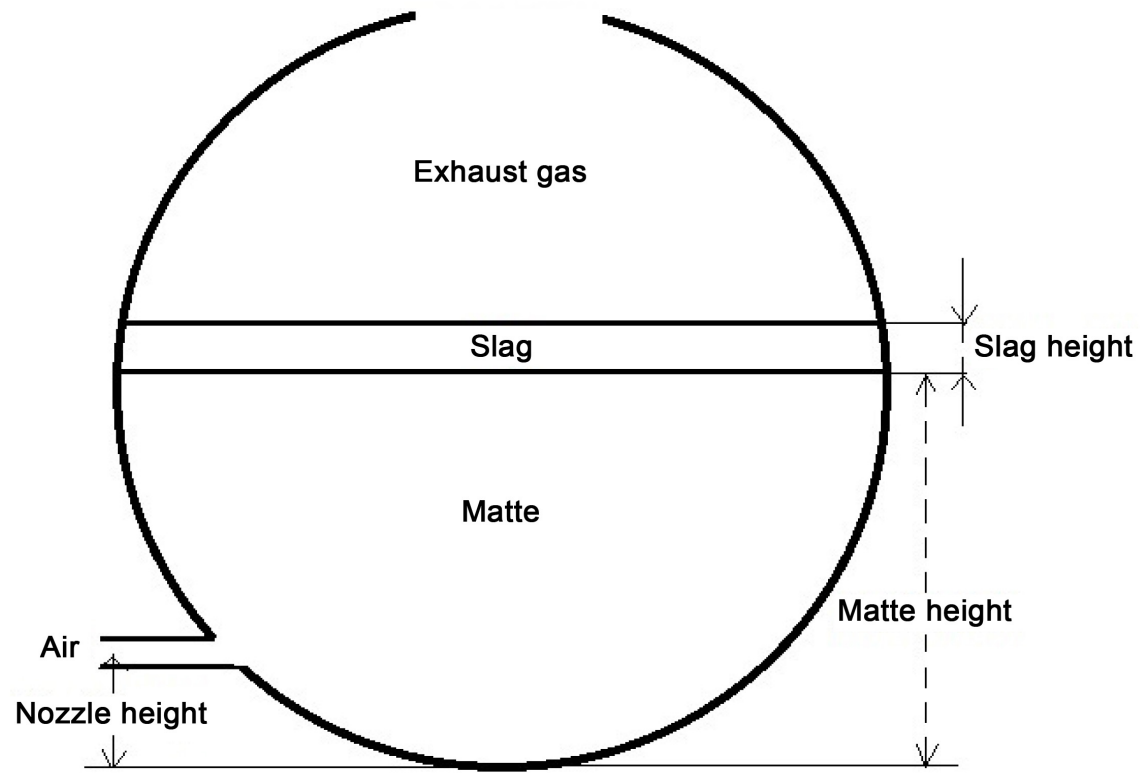

Figure 1. The phases and dimensions of the 2D copper converter.

slag height and air injection velocity were kept constant at $2.0 \mathrm{~m}, 0.1 \mathrm{~m}$, and 10 $\mathrm{m} \cdot \mathrm{s}^{-1}$, respectively. Matte and slag distribution inside the converter were monitored for each value of the nozzle height, namely $0.1,0.25$ and $0.5 \mathrm{~m}$.

Figures 2-7 depict the distribution of matte and slag for the three nozzle heights considered. As the time from the start of air injection elapses, air bubbles are formed in the matte and rise towards the slag and the converter mouth. The matte and the slag are stirred by the air bubbles and are pushed from the left side of the converter to the right one. By comparison of the Figures 2-4, it can be appreciated that as the nozzle height is increased from 0.1 to $0.5 \mathrm{~m}$, the matte located at the converter bottom becomes less and less agitated.

Figures 5-7 show the distribution of the slag inside the converter for lance heights of $0.1,0.25$ and $0.5 \mathrm{~m}$, respectively. The majority of slag remains floating above the matte, however it is observed that small amounts of slag are mixed with the matte at the bottom and right section of the converter. It can be observed that as the nozzle height is increased, the mixing of the slag with the mate is decreased. Remarkably, the thickness of the slag layer that floats in the matte at the right side of the converter is increased as the nozzle height is increased.

Related to the bubbling to jetting transition during air injection, it is reported that this phenomenon is properly characterized through the dimensionless $\mathrm{Ku}$ tateladze number $(\mathrm{Ku})$ [16] [17], which considers the most important forces that determine this transition. These forces are: air inertial forces, bubble buoyancy 


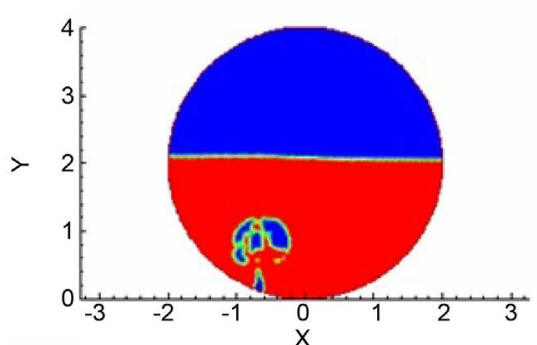

(a)

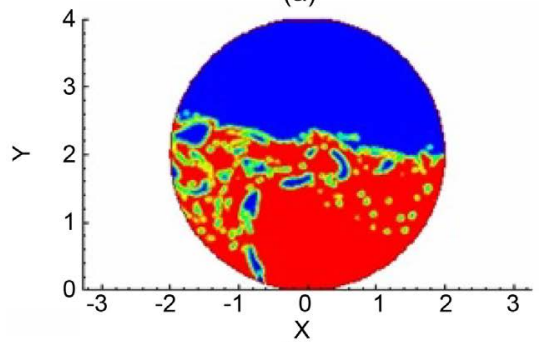

(c)

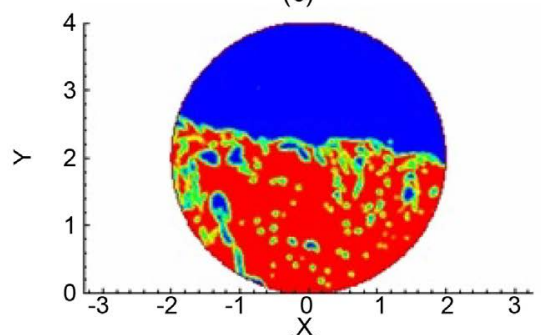

(e)

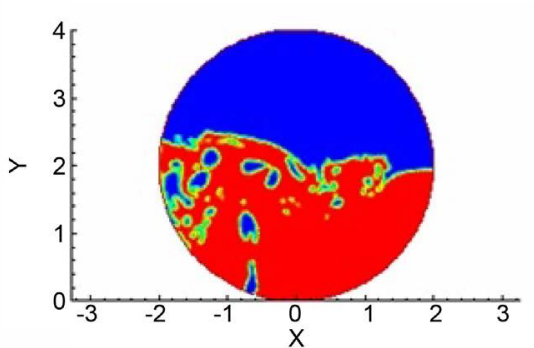

(b)

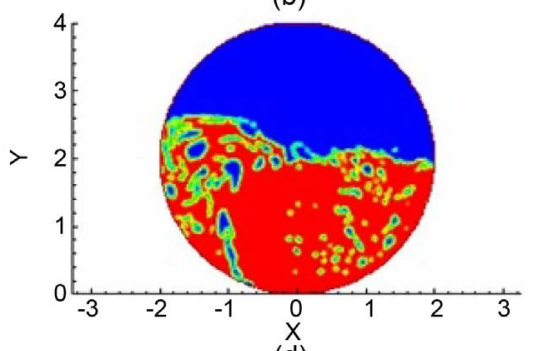

(d)

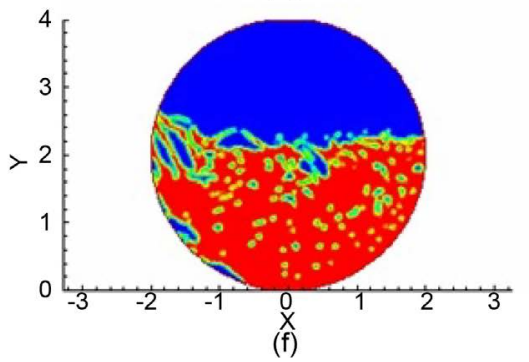

Figure 2. Matte distribution for nozzle height $=0.1 \mathrm{~m}$. The red phase is matte. Time elapsed from the start of blowing: (a) $1 \mathrm{~s}$, (b) $3 \mathrm{~s}$, (c) $5 \mathrm{~s}$, (d) $7 \mathrm{~s}$, (e) $9 \mathrm{~s}$, (f) $11 \mathrm{~s}$.

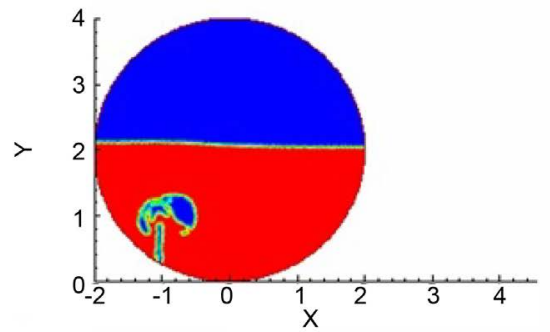

(a)

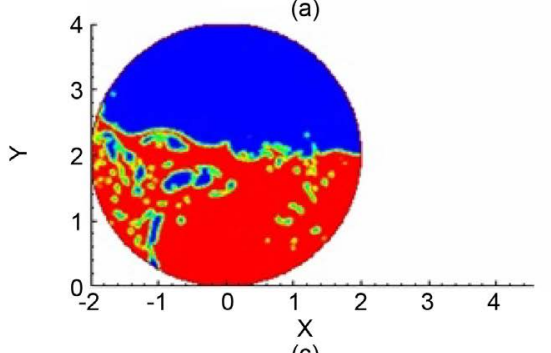

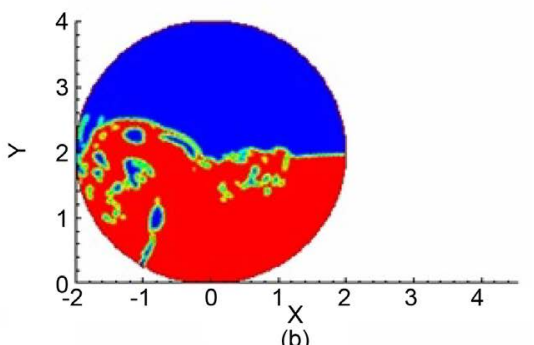

(b)

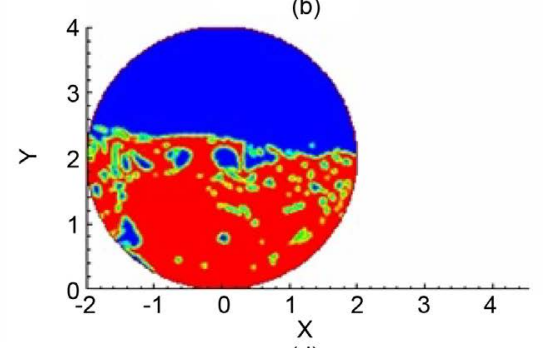

(d)

Figure 3. Matte distribution for nozzle height $=0.25 \mathrm{~m}$. The red phase is matte. Time elapsed from the start of blowing: (a) $1 \mathrm{~s}$, (b) $3 \mathrm{~s}$, (c) $6 \mathrm{~s}$, (d) $8 \mathrm{~s}$.

forces, gravity forces, and tension forces. Ku number is defined in this way [17]:

$$
K u=v \sqrt{\rho_{a}}\left[\sigma_{m} g\left(\rho_{m}-\rho_{a}\right)\right]^{-0.25}
$$




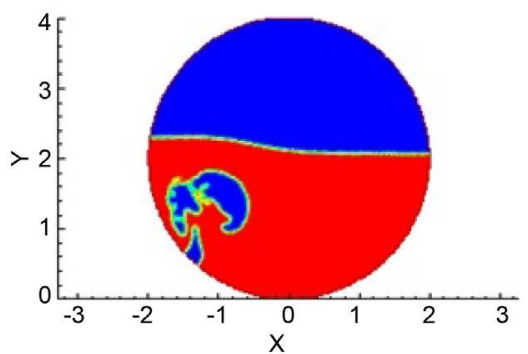

(a)

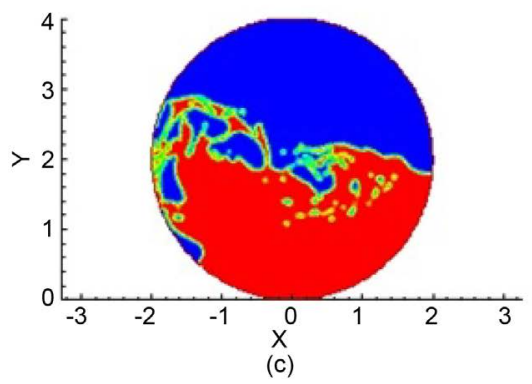

Figure 4. Matte distribution for nozzle height $=0.5 \mathrm{~m}$. The red phase is matte. Time elapsed from the start of blowing: (a) $1 \mathrm{~s}$, (b) $2 \mathrm{~s}$, (c) $3 \mathrm{~s}$, (d) $4 \mathrm{~s}$.

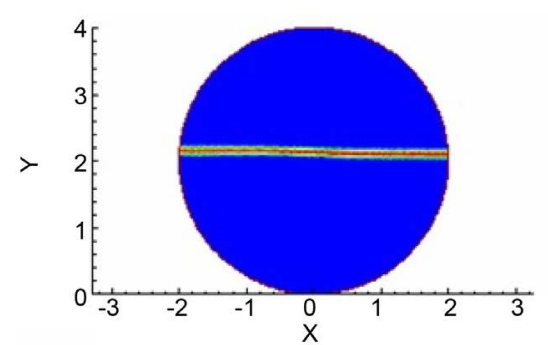

(a)
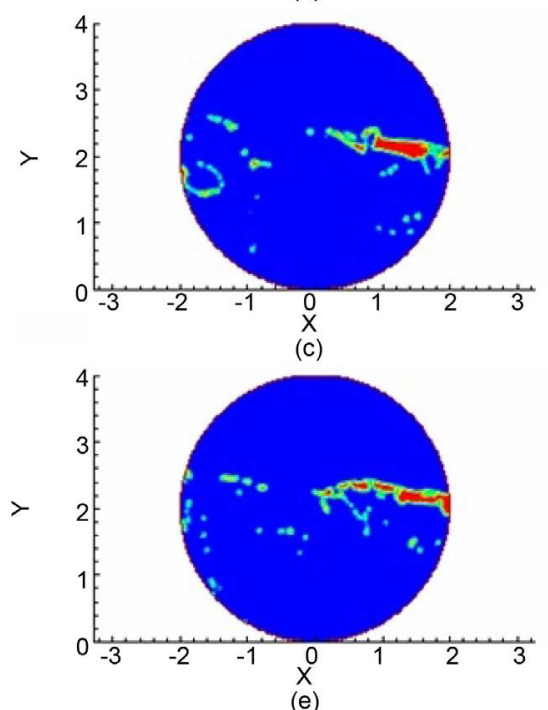

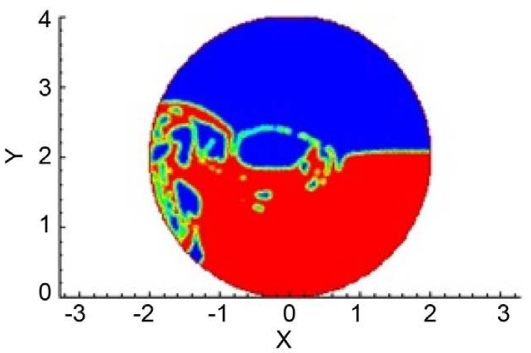

(b)

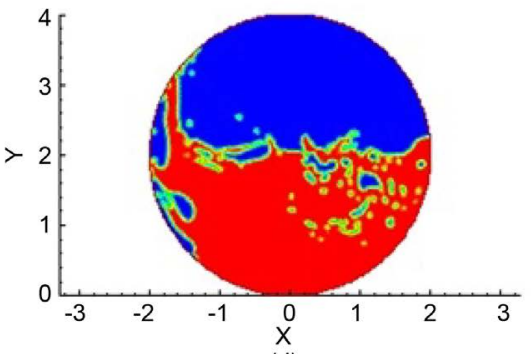

(d)

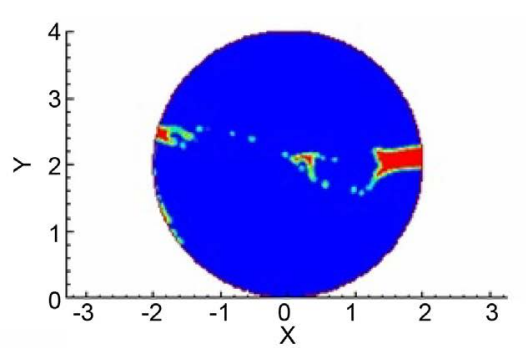

(b)
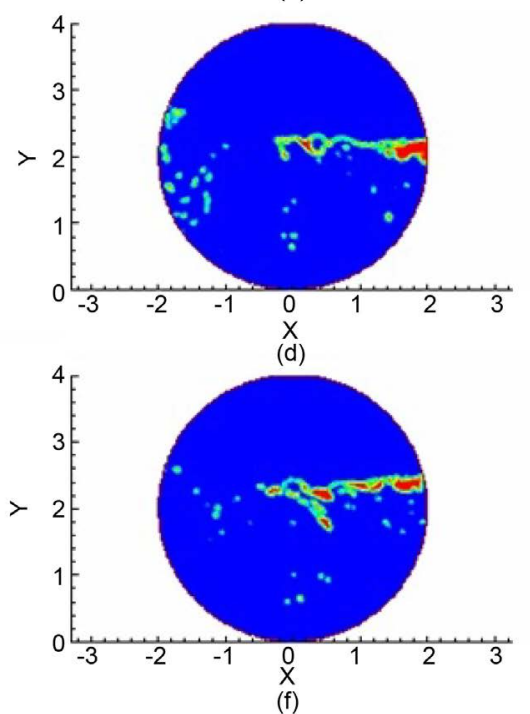

Figure 5. Slag distribution for nozzle height $=0.1 \mathrm{~m}$. The red phase is slag. Time elapsed from the start of blowing: (a) $1 \mathrm{~s}$, (b) $3 \mathrm{~s}$, (c) $5 \mathrm{~s}$, (d) $7 \mathrm{~s}$, (e) $9 \mathrm{~s}$, (f) $11 \mathrm{~s}$.

where $V$ is the air injection velocity, $\rho_{a}$ is the air density, $\rho_{m}$ is the molten matte density, $\sigma_{m}$ is the matte surface tension, and $\mathrm{g}$ is the gravity force. For the PSC, it 


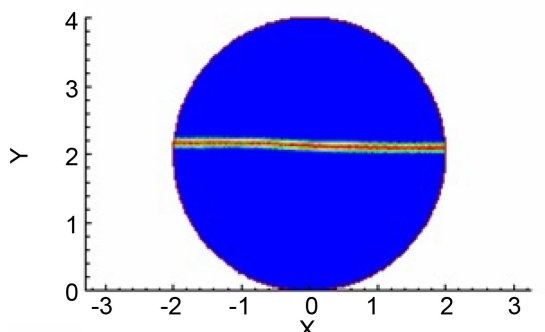

(a)

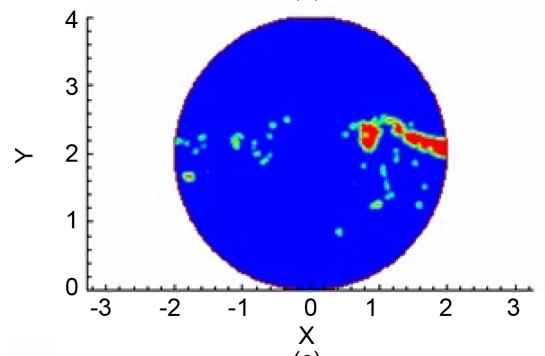

(c)

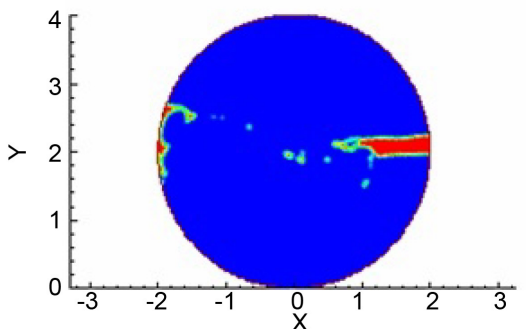

(b)

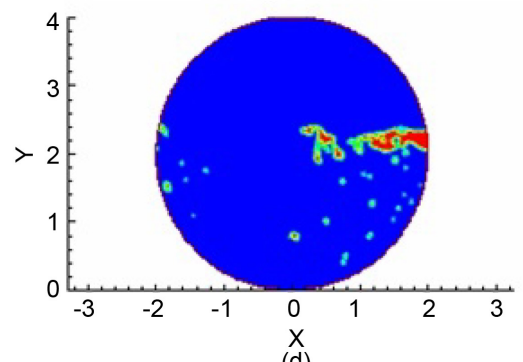

$\underset{(d)}{X}$

Figure 6. Slag distribution for nozzle height $=0.25 \mathrm{~m}$. The red phase is slag. Time elapsed from the start of blowing: (a) $1 \mathrm{~s}$, (b) $3 \mathrm{~s}$, (c) $6 \mathrm{~s}$, (d) $8 \mathrm{~s}$.

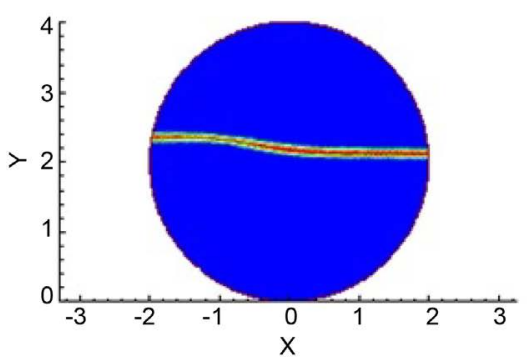

(a)

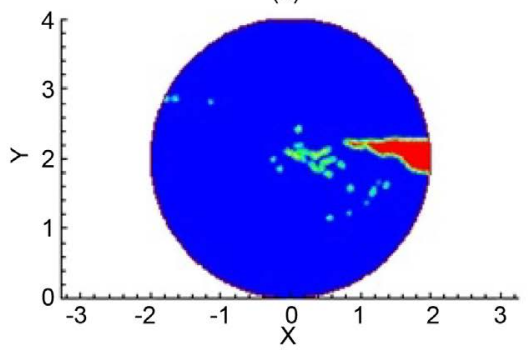

(c)

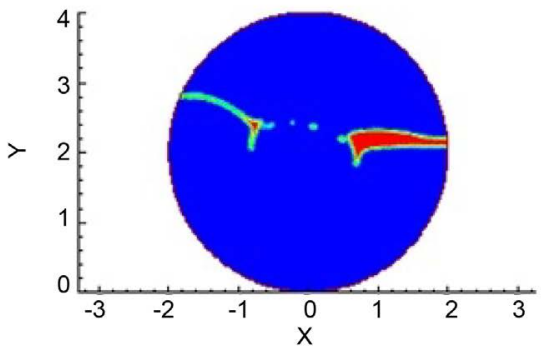

(b)

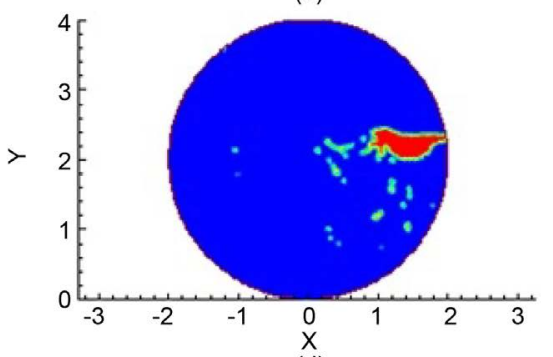

(d)

Figure 7. Slag distribution for nozzle height $=0.5 \mathrm{~m}$. The red phase is slag. Time elapsed from the start of blowing: (a) $1 \mathrm{~s}$, (b) $2 \mathrm{~s}$, (c) $3 \mathrm{~s}$, (d) $4 \mathrm{~s}$.

is reported that the transition from bubbling to jetting occurs for $K u \geq 3.4832$, which corresponds to air injection velocities greater than $50 \mathrm{~m} \cdot \mathrm{s}^{-1}$ [16]. Results of this work are consistent with those presented in [7] and [15].

\section{Conclusions}

A numerical analysis of the multiphase flow in a Peirce-Smith copper converter was carried out using the Computational Fluid Dynamics technique. Three phases were considered, namely molten matte, molten slag, and air. The matte 
height, the slag height, and the air injection velocity were kept constant along the computer runs. The aim of the numerical analysis was to study the influence of the nozzle height on the phase distributions inside the converter. From the numerical results of the two-dimensional transient computer runs the following conclusions arise:

1) As the nozzle height is increased, the matte agitation at the bottom converter is decreased.

2) As the nozzle height is increased, the thickness of the slag layer at the right side of the converter is increased.

3) As the nozzle height is increased, the mixing of the slag with the mate is decreased.

4) The nozzle height parameter plays a significant role in the phase distributions inside the converter.

Future work must consider the three-dimensional behavior of the copper converter.

\section{References}

[1] Davenport, W.G., King, M., Schlesinger, M. and Biswas, A.K. (2002) Extractive Metallurgy of Copper. Pergamon, Oxford.

[2] Liow, J.L. and Gray, N.B. (1990) Slopping Resulting from Gas Injection in a Peirce-Smith Converter: Water Modelling. Metallurgical Transactions B, 21B, 987-996. https://doi.org/10.1007/BF02670269

[3] Hoefele, E.O. and Brimacombe, J.K. (1979) Flow Regimes in Submerged Gas Injection. Metallurgical Transactions B, 10B, 631-648. https://doi.org/10.1007/BF02662566

[4] Brimacombe, J.K., Meredith, S.E. and Lee, R.G.H. (1984) High-Pressure Injection of Air into a Peirce-Smith Copper Converter. Metallurgical Transactions B, 15B, 243-250. https://doi.org/10.1007/BF02667327

[5] Vaarno, J., Pitkala, J., Ahokainen, T. and Jokilaakso, A. (1997) Modeling Gas Injection of a Peirce-Smith Converter. International Conference on CFD in Mineral \& Metal Processing and Power Generation, CSIRO, Australia, 297-306.

[6] Valencia, A., Paredes, R., Rosales, M., Godoy, E. and Ortega, J. (2004) Fluid Dynamics of Submerged Gas Injection into Liquid in a Model of Copper Converter. International Communications on Heat and Mass Transfer, 31, 21-30. https://doi.org/10.1016/S0735-1933(03)00198-2

[7] Valencia, A., Rosales, M., Paredes, R., Leon, C. and Moyano, A. (2006) Numerical and Experimental Investigation of the Fluid Dynamics in a Teniente Type Copper Converter. International Communications on Heat and Mass Transfer, 33, 302-310. https://doi.org/10.1016/j.icheatmasstransfer.2005.12.009

[8] Almaraz, A., Lopez, C., Arellano, I., Barron, M.A., Jaramillo, D., Reyes, F. and Plascencia, G. (2014) CFD Modelling of Fluid Flow in a Peirce-Smith Converter with More Than One Injection Points. Minerals Engineering, 56, 102-108. https://doi.org/10.1016/j.mineng.2013.11.001

[9] Almaraz, A., Lopez, C., Barron, M.A. and Plascencia, G. (2013) Numerical and Physical Modeling of Turbulence in a Peirce-Smith Copper Converter. Journal of Materials Science and Engineering A, 3, 510-518. 
[10] Bird, R.B., Stewart, W.E. and Lightfoot, E.N. (2002) Transport Phenomena. 2nd Edition, Wiley, New York.

[11] Thomas, B.G., Yuan, Q., Sivaramakrishnan, S., Shi, T., Vanka, S.P. and Assar, M.B. (2001) Comparison of Four Methods to Evaluate Fluid Velocities in a Continuous Slab Casting Mold. ISIJ International, 41, 1262-1271. https://doi.org/10.2355/isijinternational.41.1262

[12] Hirt, C.W. and Nichols, B.D. (1981) Volume of Fluid (VOF) Method for the Dynamics of Free Boundaries. Journal of Computational Physics, 39, 201-225. https://doi.org/10.1016/0021-9991(81)90145-5

[13] Fluent 6.1 User's Guide (2003) Lebanon, NH.

[14] Ferziger, J.H. and Peric, M. (1999) Computational Methods for Fluid Dynamics, Springer, Berlin. https://doi.org/10.1007/978-3-642-98037-4

[15] Barron, M.A. and Hernandez, C.A. (2016) Air-Slag-Matte Interaction in a Peirce-Smith Copper Converter. The 2016 International Conference on Modeling, Simulation and Visualization Methods, WorldComp 2016, Las Vegas, 25-28 July 2016, 28-30.

[16] Barron, M.A., Lopez, C., Plascencia, G. and Hilerio, I. (2010) Large Eddy Simulation of Bubbling-Jetting Transition in a Bottom Blown Copper Converter. The 2010 International Conference on Modeling, Simulation and Visualization Methods, WorldComp 2010, Las Vegas, 12-15 July 2010.

[17] Sundar, R. and Tan, R.B.H. (1999) A Model for Bubble-to-Jet Transition at a Submerged Orifice. Chemical Engineering Science, 54, 4053-4060.

https://doi.org/10.1016/S0009-2509(99)00152-9 